\title{
Pulmonary Tuberculosis Reactivation: Triggered by the Descent in Altitude?
}

\author{
Reativação de Tuberculose Pulmonar: Causada pela \\ Descida em Altitude?
}

Filipa BIANCHI-DE-AGUIAR $₫ 1$, Rafaela CAMPANHA², Cátia GUIMARÃES², Margarida SIMÕES-RAPOSO² Acta Med Port 2018 Oct;31(10):589-592 - https://doi.org/10.20344/amp.10151

\begin{abstract}
High altitudes are linked to decreased rates of pulmonary tuberculosis infection, disease and mortality. However, its relevance as a trigger for pulmonary tuberculosis reactivation in immunocompetent patients is not documented. A 28-year-old healthy Nepalese female was admitted in the emergency department with sudden left pleuritic back pain with shortness of breath, two weeks after arriving in Lisbon, having arrived from Kathmandu and undergone a change in altitude of $1400 \mathrm{~m}$. She also had evening low-grade fever and fatigue since she arrived. Her mother-in-law had died of tuberculosis two years before. Chest radiography and computed tomography scan showed a left upper lobe consolidation. Laboratory analyses were unremarkable, except for erythrocyte sedimentation rate of $79 \mathrm{~mm} / \mathrm{sec}$. Human immunodeficiency virus serology, blood cultures and urinary antigen testing were negative. Bronchial secretions' cultures became positive for Mycobacterium tuberculosis complex. The patient was started on anti-tuberculous treatment and made a steady recovery. This case reports a probable reactivation of pulmonary tuberculosis infection that could have been triggered by altitude differences.
\end{abstract}

Keywords: Altitude; Tuberculosis, Pulmonary

\section{RESUMO}

A altitude elevada está associada a menores taxas de infeção, doença e mortalidade por tuberculose pulmonar. Contudo, a sua relevância como fator desencadeante da reativação de tuberculose pulmonar não está documentada. Uma mulher nepalesa de 28 anos recorreu à urgência com dor dorsal esquerda, súbita, pleurítica, associada a falta de ar, duas semanas após ter chegado a Lisboa. Tinha voado de Katmandu, que difere em altitude em $1400 \mathrm{~m}$. Apresentava ainda febre baixa vespertina e astenia desde a chegada. A sogra tinha falecido com tuberculose dois anos antes. A radiografia de tórax e a tomografia computadorizada revelaram consolidação do lobo superior esquerdo. As análises não apresentavam alterações de relevo, exceto uma velocidade de sedimentação de $79 \mathrm{~mm} / \mathrm{seg}$. A serologia para o vírus da imunodeficiência humana, hemoculturas e testes urinários de antigénios eram negativos. A cultura de secreções brônquicas foi positiva para Mycobacterium tuberculosis complex. Iniciou-se tratamento anti-tuberculoso e observou-se melhoria progressiva e completa. Este caso descreve uma possível reativação de tuberculose pulmonar que pode ter sido despoletada por diferenças em altitude.

Palavras-chave: Altitude; Tuberculose Pulmonar

\section{INTRODUCTION}

Tuberculosis (TB) remains the world's second largest killer due to a single infectious agent. It is estimated that about one-quarter of the world's population has latent TB. ${ }^{1}$

Most TB reactivations occur in people with compromised immune systems, due to ageing and conditions such as chronic kidney failure, HIV, malnutrition, diabetes, or the use of tobacco, but can also occur in immunocompetent individuals. ${ }^{2-4}$

High altitude is known to be related to diminished rates of pulmonary TB (PTB) infection, disease and mortality, having been historically recommended for its care before the antibiotic era ${ }^{4-7}$ Despite this well documented effect, we did not find any published cases that took into consideration the impact of altitude on reactivation. Through this case we reflect on the possibility that descent in altitude could have contributed to PTB reactivation in an immunocompetent host.

\section{CASE PRESENTATION}

A 28-year-old previously healthy Nepalese female was admitted in the emergency department with complaints of sudden right pleuritic back pain with shortness of breath, two weeks after landing in Lisbon, having flown from Katmandu (altitude $1400 \mathrm{~m}$ ) to visit her husband. She also had low-grade evening fever, anorexia and fatigue since she arrived. She denied productive cough or other upper respiratory symptoms, perceived weight loss, lumps, or other symptoms. She had had contact with her motherin-law, who had died of tuberculosis two years before. She told us she had no immunisations in Nepal. She had a history of a normal pregnancy two years before, with normal delivery. She took no regular medication and denied history of allergies, tobacco or illicit drug use or any trauma. During her two-month hospital admission, only low-grade fever with maximum temperature of $37.5^{\circ} \mathrm{C}$ in the evenings and slight weight loss (less than $10 \%$ of total weight) was documented, with persistence of the other symptoms. Physical examination was unremarkable.

Her white cell count, hemoglobin, liver biomarkers, thyroid and renal function, and D-Dimers were within normal

1. Unidade Funcional 4. Serviço de Medicina. Hospital de S. Francisco Xavier. Centro Hospitalar de Lisboa Ocidental. Lisboa. Portugal.

2. Serviço de Pneumologia. Hospital de Egas Moniz. Centro Hospitalar de Lisboa Ocidental. Lisboa. Portugal.

$\triangle$ Autor correspondente: Filipa Bianchi-de-Aguiar. filipamba@gmail.com

Recebido: 28 de dezembro de 2017 - Aceite: 06 de abril de 2018 | Copyright $\odot$ Ordem dos Médicos 2018 
range; C-reactive protein (CRP) was $0.8 \mathrm{mg} / \mathrm{L}$ (normal < $0.5 \mathrm{mg} / \mathrm{L}$ ) and erythrocyte sedimentation rate (ESR) 79 $\mathrm{mm} / \mathrm{h}$. Gel electrophoresis of proteins showed an indefinite polyclonal pattern. HIV negative; antinuclear antibody (ANA), anti-neutrophil cytoplasmic antibody (ANCA) and serum ACE were negative.

Chest radiography showed poorly defined left upper lobe consolidation (Fig. 1), Computed tomography angiography (CTA) scan excluded thromboembolism or lung infarction and confirmed an alveolar consolidation of the left upper lobe's posterior segment, reaching the oblique fissure and contacting the pleura, but with no pleural effusion (Fig. 2). There were also many micronodular structures adjacent to it, and increased lymph nodes in aortopulmonary location and anterior mediastinum on the same side.

Aerobic and anaerobic blood cultures were negative, as well as Legionella pneumophila and Streptococcus pneumoniae urinary antigens. A transthoracic biopsy was attempted unsuccessfully, since a mild pneumothorax was developed during the procedure. Given the epidemiological background, latent tuberculosis was most certain, so we did not perform neither tuberculin skin test (TST) nor interferongamma release assays (IGRA), since they wouldn't be helpful to diagnose tuberculosis-infection.

Two bronchofibroscopies were carried out and did not reveal any bronchial lesions, besides discrete mucous membrane inflammation and some mucopurulent secretions on the left superior bronchus. On the first no biopsies were made in the absence of lesions, but they were done on the second bronchofibroscopy, in the attempt to reach a diagnosis. Histopathology showed mild lymphocyte infiltration and the absence of malignant cells. Bronchoalveolar lavage (BAL) showed lymphocytic alveolitis (45\% lymphocytes, 44\% monocytes/macrophages), with normal immunophenotyping flow cytometry and cytology. Microscopic and microbiological studies of this BAL were negative for bacteria (including Legionella), mycobacteria, fungus and viruses. This sample's polymerase chain reaction $(\mathrm{PCR})$ was negative for mycobacteria.

Regarding the first samples of bronchial secretions, direct microscopic and microbiological analyses were negative for bacteria (except oral saprophyte Corynebacterium pseudodiphteriticum meaning probable contamination), fungus and viruses. However, the sample obtained from the second bronchofibroscopy was cultured and was positive for multi sensitive Mycobacterium tuberculosis complex, with no mutations on $r p o B$ gene. The diagnosis of PTB infection was then presumed.

Without suspicion of resistance, the patient was empirically started on a four drug regime with rifampicin,

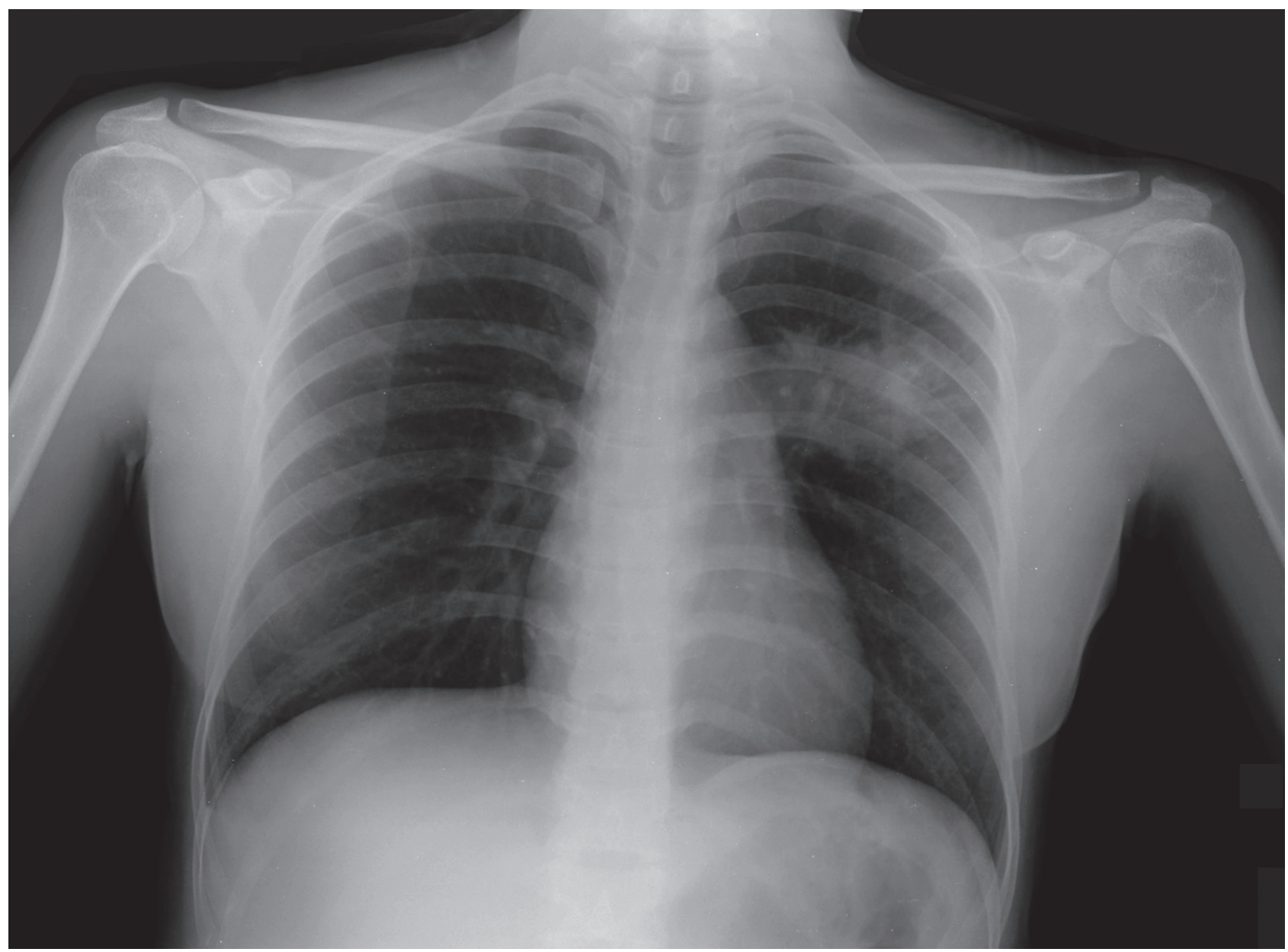

Figure 1 - Postero-anterior chest radiography at the time of onset 


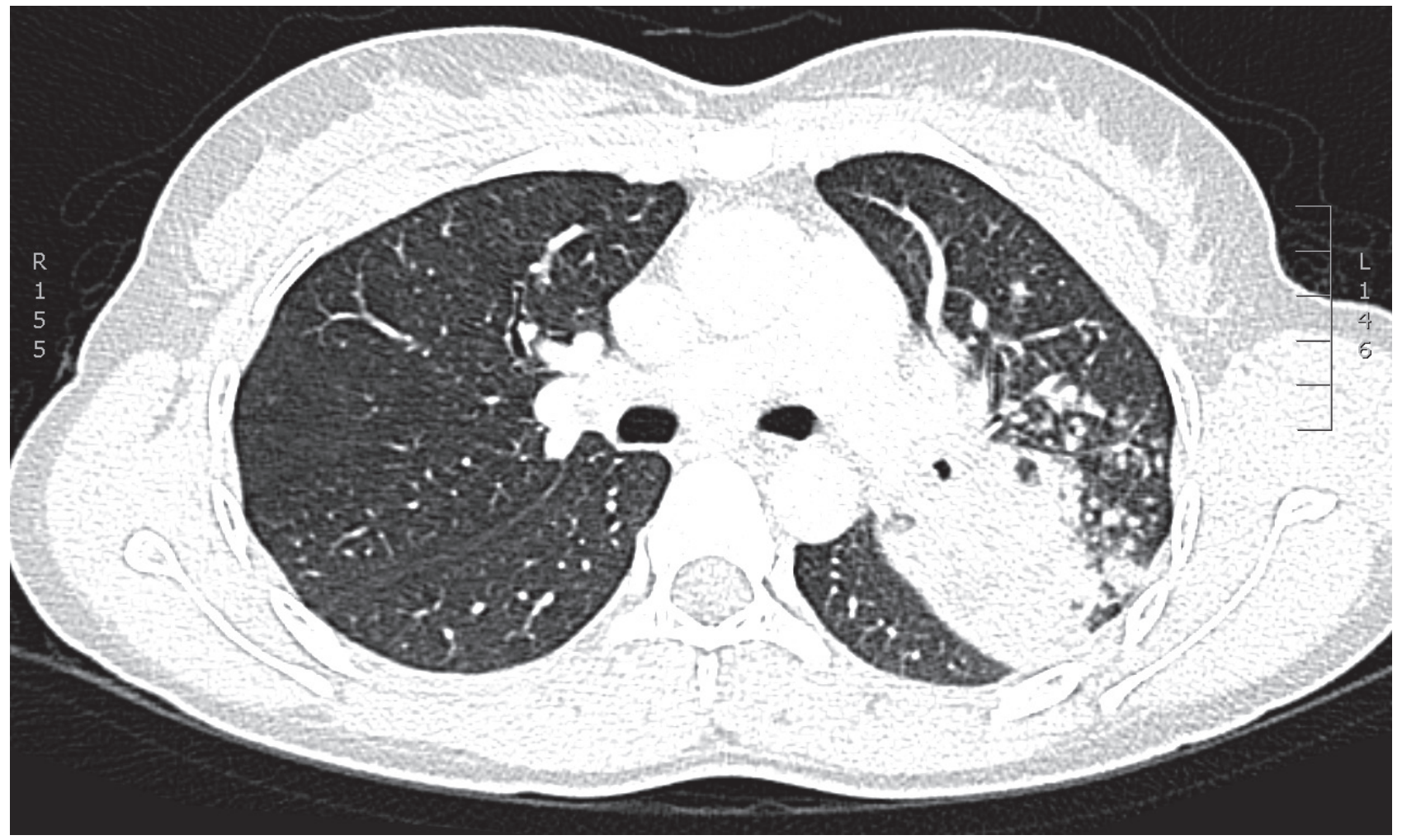

Figure 2 - Axial chest CT-scan at the time of onset

ethambutol, isoniazid and pyrazinamide for two months, and other four months with rifampicin and isoniazid. The treatment was tolerated and the patient gradually recovered from the complaints. She gained $6 \mathrm{~kg}(10 \%$ of total body weight) and presented a completely normal chest radiography at the end of treatment.

\section{DISCUSSION}

Regarding differential diagnosis, one of the first hypothesis would be thromboembolism with lung infarction, since it could be responsible for the acute onset with pleuritic chest pain and breathlessness, but they were excluded by negative $D$ dimers and a clear angio-CT. Lymphoma should also be considered, since it could present with a rapidly progressive lung consolidation, pleuritic chest pain, fatigue, and night-time fever, but it is distinguished from TB by histopathology, immunophenotyping flow cytometry and cytology, which were negative in this case. Systemic autoimmune diseases could occasionally present with lung features, like in lupus erythematosus, sarcoidosis, and Wegener granulomatosis. ${ }^{8}$ They could not be excluded given the lymphocytic alveolitis found on the bronchoalveolar lavage. However, ANA, ANCA and serum ACE were negative, as well as the histopathology. According to the Centers for Disease Control and Prevention (CDC), there is no specific respiratory endemic infection to be suspected in a Nepalese immigrant. However, due to important levels of air pollution in the Katmandu valley, people often suffer from respiratory tract infections, including common sinusitis, otitis, bronchitis, and pneumonia. ${ }^{9} \mathrm{~A}$ pneumonia could explain the lung consolidation, but it usually presents with more respiratory symptoms and increased CRP. More rarely, fungal pneumonia could present with a range of features including lung consolidation with indolent clinical presentation. Nevertheless, there were no relevant epidemiologic exposures and culture results to support it. Finally, lung cancer can present with chest pain, dyspnea, and pulmonary consolidation, despite the lack of known risk factors. It was ruled out by histopathology.

Cases of TB reactivation are more likely to occur in people with latent TB, who have compromised immune systems, such as the elderly, individuals with chronic kidney failure, HIV, malnutrition or diabetes, or who are smokers. ${ }^{4}$ However, it can also occur in immunocompetent hosts.

In these, TB reactivation may remain undiagnosed and potentially infectious for two to three years or longer, with development of symptoms only late in the course of the disease, and commonly involving the apical posterior segments of the upper lobes or the superior segment of the lower lobe of the lung, as we have seen in this case..$^{10}$ It is also frequent to find normal routine haematological and biochemical laboratory studies in the setting of pulmonary $\mathrm{TB}$, with possible changes appearing late in the disease, such as normocytic anemia, leucocytosis, or, more rarely, monocytosis, hyponatremia, hypoalbuminemia and hypergammaglobulinemia. The C-reactive protein (CRP), however, can be elevated in up to $85 \%$ of patients at the onset, which was also normal in this case. ${ }^{10}$

Therefore, PTB diagnosis can be challenging, requiring a high level of suspicion and multiple diagnostic procedures,,$^{10}$ as we have seen in this case. Persistence may be demanded, especially when we verify a previous 
contact with the disease and a travel history to a country with a high incidence of infection such as Nepal, with an incidence of 154 cases per 100000 people per year. ${ }^{11}$ Cultures for mycobacteria should be promptly performed, even if bronchofibroscopies may be needed to gather the required samples. In this case, cultures were only requested following the second bronchofibroscopy, and may have been a reason for delay.

This case also led us to consider the possibility that the descent in altitude could trigger disease reactivation in a patient with latent PT. In fact, high altitude is widely known to be associated to diminished rates of PTB infection, disease and mortality, having been historically recommended for PT's care before the antibiotic era. ${ }^{5-7,10,12,13}$ The mechanisms of the altitude-mediated effect are still poorly understood, but may include effects on bacterial replication and transmission. ${ }^{14}$ It is well known that in vitro multiplication of Mycobacterium tuberculosis is highly decreased by low oxygen tension, as it is found in high altitudes. ${ }^{15,16}$ It has also been reasoned that there is a germicide capacity of altitudeassociated UV light and ${ }^{17}$ reduced humidity. ${ }^{18,19}$

Studies have confirmed this effect by dividing populations who lived as little as $500 \mathrm{~m}$ altitude apart. ${ }^{5}$ Therefore, the difference between Katmandu, altitude 1400 m, and Lisbon, mostly sea level, could be relevant.

Despite this well documented altitude effect, we did not find any published cases that considered its role on PTB reactivation. Therefore, more research is definitely needed to clarify the role of the descent in altitude as a risk factor of tuberculosis reactivation.

\section{REFERENCES}

1. World Health Organization. Tuberculosis: Fact Sheet. Geneva: WHO; 2018.

2. Hongguang C, Min L, Shiwen J, Fanghui G, Shaoping H, Tiejie G, et al. Impact of diabetes on clinical presentation and treatment outcome of pulmonary tuberculosis in Beijing. Epidemiol Infect. 2015;143:150-6.

3. Oursler KK, Moore RD, Bishai WR, Harrington SM, Pope DS, Chaisson RE. Survival of patients with pulmonary tuberculosis: clinical and molecular epidemiologic factors. Clin Infect Dis. 2002;34:752-9.

4. Robert-Horsburgh C. www.uptodate.com. Epidemiology of tuberculosis. [accessed 2017 Aug 10]. Available from https://www.uptodate.com/ contents/epidemiology-of-tuberculosis.

5. Mansoer JR, Kibuga DK, Borgdorff MW. Altitude: a determinant for tuberculosis in Kenya? Int J Tuberc Lung Dis. 1999:3:156-61.

6. Saito M, Pan WK, Gilman RH, Bautista CT, Bamrah S, Martín CA, et al. Comparison of altitude effect on mycobacterium tuberculosis infection between rural and urban communities in Peru. Am. J. Am J Trop Med Hyg. 2006;75:49-54.

7. Olender S, Saito M, Apgar J, Gillenwater K, Bautista CT, Lescano $A G$, et al. Low prevalence and increased household clustering of Mycobacterium tuberculosis infection in high altitude villages in Peru. Am J Trop Med Hyg. 2003;68:721-7.

8. Cojocaru M, Cojocaru IM, Silosi I, Vrabie CD. Pulmonary manifestations of systemic autoimmune diseases. Maedica. 2011;6:224-9.

9. Shlim DR. wwwnc.cdc.gov. Nepal. [Accessed 2018 Mar 12]. Available from https://wwwnc.cdc.gov/travel/yellowbook/2018/select-destinations/ nepal.

10. Pozniak A, Fordham R, Baron L. www.uptodate.com. Clinical

\section{Learning points / take home messages}

- TB reactivation is more common in people with compromised immune systems, but it can also occur in immunocompetent hosts.

- TB in the immunocompetent host is often a diagnosis that requires high level of suspicion and persistence, mainly when it is manifested insidiously and with few laboratory and clinical signs. Epidemiologic history is very important.

- Altitude is a known influencing factor on pulmonary tuberculosis disease and it is reasonable to think it may influence reactivation.

- More research is needed to clarify the role of the descent in altitude as a risk factor of tuberculosis reactivation.

\section{PROTECTION OF HUMANS AND ANIMALS}

The authors declare that the procedures were followed according to the regulations established by the Clinical Research and Ethics Committee and to the Helsinki Declaration of the World Medical Association.

\section{DATA CONFIDENTIALITY}

The authors declare having followed the protocols in use at their working center regarding patients' data publication.

\section{PATIENT CONSENT}

Obtained.

\section{CONFLICTS OF INTEREST}

All authors report no conflict of interest.

\section{FUNDING SOURCES}

This research received no specific grant from any funding agency in the public, commercial, or not-for-profit sectors.

manifestations and complications of pulmonary tuberculosis. [Accessed 2017 Aug 10]. Available from https://www.uptodate.com/contents/ clinical-manifestations-and-complications-of-pulmonary-tuberculosis.

11. World Health Organization. Global tuberculosis report 2017. Geneva: WHO; 2017.

12. Eisen S, Pealing L, Aldridge RW, Siedner MJ, Necochea A, Leybell I. Effects of ascent to high altitude on human antimycobacterial immunity. PLoS One. 2013;8:e74220.

13. Pérez-Padilla R, Franco-Marina F. The impact of altitude on mortality from tuberculosis and pneumonia. Int J Tuberc Lung Dis. 2004:8:131520.

14. Vargas $M H$, Furuya ME, Pérez-Guzmán C. Effect of altitude on the frequency of pulmonary tuberculosis. Int $\mathrm{J}$ Tuberc Lung Dis. 2004:8:1321-4.

15. Meylan PR, Richman DD, Kornbluth RS. Reduced intracellular growth of mycobacteria in human macrophages cultivated at physiologic oxygen pressure. Am Rev Respir Dis. 1992;145:947-53.

16. Meylan PR, Richman DD, Kornbluth RS. Oxygen tensions and mycobacterial infections. Clin Infect Dis. 1992;15:372-3.

17. Riley RL, Knight M, Middlebrook G. Ultraviolet susceptibility of BCG and virulent tubercle bacili. Am Rev Respir Dis. 1976:113:413-8.

18. Ko G, First MW, Burge HA. Influence of relative humidity on particle size and UV sensitivity of Serratia marcescens and Mycobacterium bovis BCG aerosols. Tuber Lung Dis. 2000:80:207-28.

19. Rustad TR, Sherrid AM, Minch KJ, Sherman DR. Hypoxia: a window into Mycobacterium tuberculosis latency. Cell Microbiol. 2009;11:1151-9. 